stated that no new development contracts had been discussed or negotiated with industry. However, that part of the Department of Scientific and Industrial Research for which he was to take formal responsibility had, since mid-October, placed further contracts in the fields of advanced computer techniques and superconductivity, to which research and development contracts amounting, respectively, to $£ 1.5$ million and $£ 200,000$ had already been announced. Work had been started on ten such contracts to a total value of $£ 287,000$, to which the Department's contribution would be some $£ 187,000$, and negotiations for a further contract of $£ 92,000$ were at an advanced stage. In addition, contracts to the value of $£ 150,000$ were being negotiated on a cost-sharing basis with industry for techniques leading to the production of improved superconducting wire composites.

Economic Planning Councils

Is replying to a question in the House of Commons on February 25, the Secretary of State for Economic Affairs, Mr. G. Brown, announced that he had set up Economic Planning Councils for the North-West, the West Midlands and the Northern Regions, and that Mr. C. F. Carter, Mr. J. A. Hunt and Mr. D. Smith, respectively, had accepted his invitation to serve as chairmen of these three Councils. The terms of reference of these Councils are to assist in formulating a regional plan, having regard to the best use of the region's resources; to advise on the steps necessary for implementing the regional plan on the basis of information and assessments provided by the Economic Planning Board; and to advise on the regional implications of national economic policies. These terms of reference and the names of the members of the Councils are given in Hansard for February 25, and the corresponding terms of reference and the members of the Welsh Economic Council and the Scottish Economic Planning Council of which the Minister of State for Wales, Mr. C. Roberts, and the Secretary of State for Scotland, or a Ministerial colleague in the Scottish Office, respectively, will be chairman, are given in written answers in the House of Commons also of February 25.

\section{Working Party on Scientific Information}

IN connexion with International Co-operation Year, a working party has been set up to bring together proposals on possible forms of international co-operation in the field of scientific information and to assess their feasibility. It is intended to prepare a memorandum on the subject for presentation to the fourteenth Pugwash Conference in April, but the working party will continue its deliberations throughout this year. The working party consists of Mr. T. M. Aitchison, Dr. H. Coblans, Mr. E. G. Hill, Miss E. J. Knight, Mr. W. J. Perkins, Mr. A. V. S. de Reuck, Miss M. Webb, and a representative of the Pugwash Group. The field is being considered under the following four headings: primary and secondary publication; retrieval; dissemination; and research on documentation. The working party will be glad to receive, in writing, views or proposals on any of these subjects. They should be sent to the convenor, Mr. A. V. S. de Reuck, the Ciba Foundation, 41 Portland Place, London, W.1.

\section{A Welcome New Precinct in London}

THe recent development of the old Stag brewery site close to Victoria Station, London, provides some remarkable contrasts in lay-out and architectural design compared with the immediate environment of this part of the metropolis. On this site have been erected seven buildings, separated by paved spaces, designed by four different architects for four separate developers. The result is an impressive variety of building in a relatively small area, but although this in itself may invite criticism, the scheme as a whole and as now realized is a vast improvement on what was there before. The site is chiefly enclosed between Bressenden Place and Palace
Street, fronting on to Victoria Street where the new Esso House occupies the commanding position; this is one of the seven buildings concerned. The others are Glen House, Portland House, Roebuck House, Watney House, Eland House and, west of Bressenden Place, Carrier House together with the small but distinguished Stag public house of pleasing octagonal design. The hub of this scheme, however, is undoubtedly Stag Place, a rectangular space $250 \mathrm{ft}$. long by $200 \mathrm{ft}$. wide, raised a foot or two above ground-level to accommodate a car park beneath, with five of the seven buildings grouped around it. It is this Stag Place which has been described as the 'welcome new precinct for London', and although at present looking very new and starved of greenery (the few trees are naturally very young), it is an oasis of calm compared with the turmoil of Victoria. Details of the scheme are given in an illustrated article in Concrete Quarterly (62; July-September; 1964, Cement and Concrete Association, London, S.W.1). From this it is evident that the basic characteristic of the whole group of buildings ". . . is the very extensive and varied use of concrete as structure and finish. All the buildings are reinforced concrete framed, many make use of precast concrete cladding panels (the best of which are undoubtedly those on the tall Portland House) and some have exposed in situ concrete elements. Concrete paving is an integral part of the scheme: Stag Place is itself paved with squares of white and grey standard flags, laid in staggered pattern and separated by bands of red brick." It will be generally conceded that much of this area of Victoria is already unrecognizable from two years ago, and it is at this juncture that it is difficult to see how this development of the Stag brewery site will be accommodated, at least aesthetically, in the overall plan of future development of tho area as a whole. Be that as it may, there is little doubt that this new Stag Place precinct will be much used and enjoyed by those living and particularly working in the area, and to this extent it is a most welcome development.

\section{Thorium, Ltd., Fifty Years of Progress}

THE origin of Thorium, Ltd., is linked with the invention of the gas mantle by Auer von Welsbach at the end of the nineteenth century, an achievement which revolutionized gas lighting and at the time provided high-intensity illumination both for streets and in the home. Although to-day comparatively few such gas lights are seen in streets, and probably an ever-diminishing number in homes, the Welsbach gas mantle is still largely used in lamps and lanterns utilizing bottled gas or paraffin as fuel, especially in Eastern countries. A gas mantlo consists essentially of a fine skeleton of thorium oxide containing a little cerium oxide, based on thorium nitrate, but involving complex chemical and physical manufacturing processes. In 1914, consequent on the outbreak of the First World War, Britain was deprived of its main source of supply of thorium nitrate, Germany. It was then that the well-known firms Hopkin and Williams, the Volker Lighting Corporation, and Howard and Sons, formed Thorium, Ltd., and established manufacture of thorium nitrate at a factory in Ilford, Essex. A recently published and beautifully designed and illustrated brochure entitled Thorium Limited: Fifty Years of Progress (Pp. 16. London: Thorium, Ltd., 1964) gives interesting details of this venture, of its growth and present greatly extended operations. Sources of thorium are briefly described; it was originally extracted from the mineral thorite, obtained from Norway; discovery of monazite in substantial quantities in heavy mineral beach sands in Brazil led to this source of thorium nitrate being used by German manufacturers, but during the First World War an alternative source of monazite was found by Thorium, Ltd,, and their associates Hopkin and Williams (Travancore), Ltd., in heavy mineral beach sands of Travancore, State of Kerala, Southern India; 